\title{
Fate of Tebuconazole in Polish Mineral Soils - Results of Simulations with FOCUS PELMO
}

\author{
Marcin Maciej Siek ${ }^{1 *}$, Tadeusz Paszko ${ }^{1}$ \\ 1 Department of Chemistry, University of Life Sciences, Akademicka 13, 20-950 Lublin, Poland \\ * Corresponding author's e-mail: maciek.siek@wp.pl
}

\begin{abstract}
The degradation of tebuconazole in the majority of Polish mineral soils withlow organic carbon content is slow, and its adsorptionis especially low in subsoils. Therefore, the fate of tebuconazole in these soils cannot be predicted based on the results of the adsorption and degradation experiments carried out in typical soils of the European Union. For this reason, the simulations of tebuconazole accumulation in Polish soils and its leaching to groundwater were carried out. The cultivation of winter cereals and winter oilseed rape was simulatedusing FOCUS PELMO in six Arenosol, Luvisol, and Chernozem profiles, representing 59\% of Polish arable mineral soils. The simulations indicated that almost all fungicide that reached the soil surface was retained in the topsoil layer of $0-15 \mathrm{~cm}$. The highest concentrations (range of $0.069-0.320 \mathrm{mg} / \mathrm{kg}$ ) were estimated for the layer $0-5 \mathrm{~cm}$. The results suggested that runoff can be the principal source of tebuconazole in surface water. It was found that the majority of tebuconazole that reached the soils was microbiologically degraded. However, in the years with unfavorable weather conditions for degradation, up to $11 \%$ of the tebuconazole that reached the soils remain undegraded. In addition to the accumulation of tebuconazole in the topsoils, the simulations indicated its very slow but constant penetration into the subsoils. The estimated concentrations of tebuconazole in percolate water were low: $<0.02 \mu \mathrm{g} / \mathrm{L}$ at the depth of $25 \mathrm{~cm},<0.002 \mu \mathrm{g} / \mathrm{L}$ at the depth of $75 \mathrm{~cm}$, and trace concentrations at the depth of $1 \mathrm{~m}$ in one profile. The obtained results were consistent with the results of the monitoring studies available in literature.
\end{abstract}

Keywords: tebuconazole, FOCUS PELMO simulations, retention, leaching

\section{INTRODUCTION}

(RS)-1-(4-chlorophenyl)-4,4-dimethyl3-(1H-1,2,4,-triazol-1-ylmethyl)-pentan-3ol,known astebuconazole, is one of the most popular azole fungicides. It is one of over a dozen triazole and imidazole fungicides currently approved for use in the European Union (EU) [European Comission, 2021a]. Tebuconazole is widely used in agriculture against fungal diseases[Tauchnitz et al., 2020], for seed treatment and as a growth retardant [Matysiak and Kaczmarek, 2013], as well as wood preservative [Bollmann et al., 2017]. In 2003, there were 16 plant protection tebuconazole-containing products registered in Poland. Their number increased to 39 in 2009 [Matyjaszczyk, 2011], and to 124 in 2021 [Ministry of Agriculture and Rural Development, 2021]. In 2019, Poland was in the $3^{\text {rd }}$ place in the EU in terms of the use of azole fungicides, with yearly sales of 1375.6 tons [European Comission, 2021b].

The extensive use of tebuconazole in agriculture has made the compound an environmental hazard. Although the maximum allowable dose of this compound is only $0.25 \mathrm{~kg} / \mathrm{ha}$ [EFSA, 2014], its maximum concentrations in rivers reach $9.1 \mu \mathrm{g} / \mathrm{L}$ [Berenzen et al., 2005] and even $670 \mu \mathrm{g} / \mathrm{L}$ in surface water from runoff [Potter et al., 2014]. Its maximum concentration in agricultural soils of the EU was detected at $0.19 \mathrm{mg} / \mathrm{kg}$ [Silva et al., 2019]. Even more worrying is the level of detection of tebuconazole in environmental samples. In the case of soils, the reported values were 12\% [Silva et al., 2019], 36\% [Hvezdova et al., 2018], and even $60 \%$ [Tauchnitz et al., 2020; Bernasconi et al., 2021]. The reported levels of detection of the compound in water 
samples were 30\% [Van Metre et al., 2017], 44\% [Berenzen et al., 2005], 72\% [De Gerónimo et al., 2014], 82\% [Kahle et al., 2008], and 90\% [Pérez et al., 2017]. Notably, in 2020, the European Commission issued Decision 2020/1161, which added 7 azole fungicides (including tebuconazole) to the watch list of the substances subjected to Union-wide monitoring in the environment due to their possible destructive effect on aquatic organisms [European Comission, 2020]. The reason is that azole fungicides areaccumulated in aquatic organisms. For example, the classic test of bioaccumulation in fish carried out using Danio rerio indicated a tebuconazole bioaccumulation factor in the range of 9.79-16.25 [Liu et al., 2016].

During the authorization procedure required by EU Directive 91/414, the pesticide leaching and the possible range of groundwater contamination have to be assessed [Comission of the European Communities, 1991]. Because the leaching of pollutants to groundwater is a very complex process, standard decision trees have been developed in the EU starting with simple laboratory measurements of the adsorption and degradation parameters. These data, together with the pesticide, soil, and climate data, are entered into one of the recommended pesticide leaching models and the first tier modeling pesticide leaching into groundwater is carried out using nine standardized worst case scenarios developed by the FOCUS group (Forum for the Coordination of the Pesticide Fate Models and their Use). In the cases where simulations indicate that the concentrations in soil water at $1 \mathrm{~m}$ depth can exceed the concentration of $0.1 \mu \mathrm{g} / \mathrm{L}$ allowed in the EU for a single pesticide, higher tier simulations are carried out (requiring more detailed adsorption and degradation data) and outdoor leaching experiments if necessary [Kördel and Klein, 2006].

Tebuconazole is rather strongly adsorbed in soils, mainly by soil organic matter. According to the Pesticide Properties Database, its mean Freundlich adsorption coefficient $\left(K_{F}\right)$ is $12.69 \mu \mathrm{g}^{1-1 / \mathrm{n}}$ $(\mathrm{mL})^{1 / n} \mathrm{~g}^{-1}$, and the coefficient normalized to organic carbon $\left(K_{F o c}\right)$ is $769 \mu \mathrm{g}^{1-1 / \mathrm{n}}(\mathrm{mL})^{1 / n} \mathrm{~g}^{-1}$ [Lewis et al., 2016]. Therefore, the fungicide is classified as slightly mobile in soils. However, its mobility can be higher in the soils with low organic matter content. Our previous study indicated that it is slightly mobile in the Ap horizon of Polish soils $\left(K_{F}\right.$ of $\left.13.1-16.9 \mu \mathrm{g}^{1-1 / \mathrm{n}}(\mathrm{mL})^{1 / \mathrm{n}} \mathrm{g}^{-1}\right)$, but its mobility is much higher in subsoils $\left(K_{F}\right.$ of $1.1-8.3 \mu \mathrm{g}^{1-1 / \mathrm{n}}$
$\left.(\mathrm{mL})^{1 / n} \mathrm{~g}^{-1}\right)$ [Siek et al., 2021]. In turn,a study on the degradation of tebuconazole indicated that the half-life (DT50) values at $20{ }^{\circ} \mathrm{C}$ were in in the range of 201-433 days in the Ap horizon and up to 3904 days in subsoils [Siek and Paszko, 2019], showing that tebuconazole is a very persistent compound in Polish soils. The values normalized to $20^{\circ} \mathrm{C}$ and moisture content at field capacity presented in the EU dossier from the field studies were much lower (range of 20.3-43.6 days, median 39.3 days). This shows that the results of simulations of tebuconazole leaching presented in the EU dossier indicating its low groundwater contamination potential may be not representative for Polish soils. Taking this into account, the modeling studies using FOCUS PELMO were carried out to estimate (i)the range of the most likely TB concentrations in soiland (ii) the range of its most likely concentrations in the soil water in profiles of the most common Polish arable soils.

\section{MATERIALS AND METHODS}

\section{Soils}

The examined soil profiles were selected from the database and soil collection of the Institute of Agrophysics of the Polish Academy of Sciences in Lublin [Bieganowski et al., 2013]. The two profiles, denoted in the Database as 611th and 805th and classified as Arenosols according to IUSS Working Group WRB [2015], represent 27\% of the coarsest Polish arable soils formed from sand. The two Luvisol profiles $\left(590^{\text {th }}\right.$ and $824^{\text {th }}$ ) represent $24.7 \%$ of the soils formed from loamy sand or loam. The $564^{\text {th }}$ Luvisol profile represents $6.9 \%$ of the soils formed from loess or loess-like formations. The 587 profile represents $1 \%$ of Polish arable soils, classified as Chernozems.

The samples were collected from the same depth: $10-15 \mathrm{~cm}$ for the Ap horizon, 45-50 cm for the upper subsoil, and $75-80 \mathrm{~cm}$ for the lower subsoil. The details concerning soil sampling were presented elsewhere [Siek and Paszko, 2019]. The locations of the examined soil profiles are presented in Figure 1 and their basic physicochemical properties are summarized in Table 1. The soil texture (Sand, Silt, and Clay contents, $\%$ ) was determined using the pipette method [ISO 11277, 2020], the soil organic carbon (OC, \%) was determined using AN SSM-5000A solid sample module of a Shimadzu TCSH analyzer, 


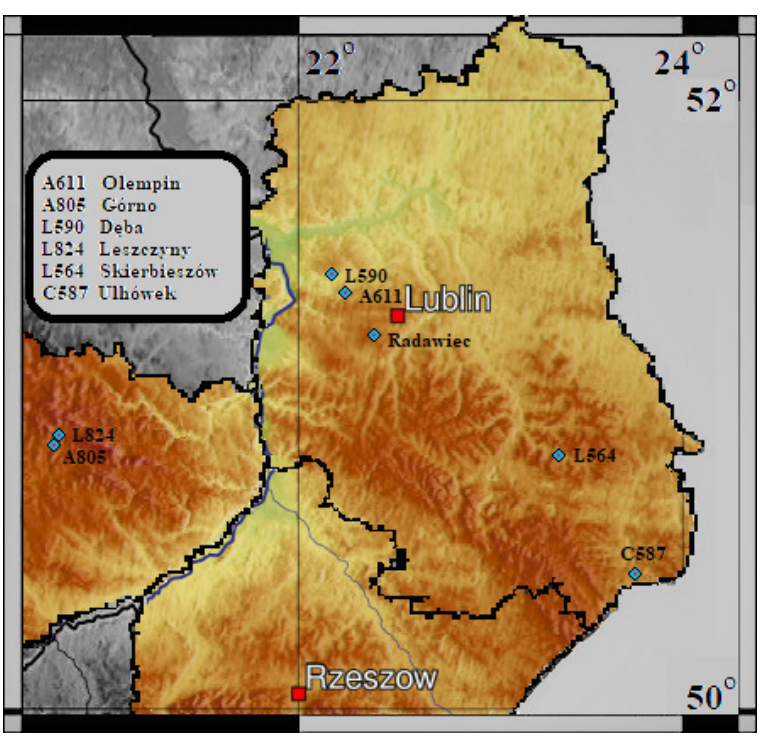

Figure 1. Locations of the examined soil profiles on the map of Poland

and $\mathrm{pH}$ was determined in $0.01 \mathrm{M} \mathrm{CaCl}_{2}$ using a glass electrode [ISO 10390, 2020]. The other soil properties are described elsewhere [Siek and Paszko, 2019; Siek et al., 2021].

\section{Parameterization of PELMO}

The pesticide leaching model PELMO is a compartment model simulating pesticide transport in the unsaturated soil system within and below the plant root zone, which has been developed since 1989 [Klein et al., 1997; Klein, 2018]. It is one of the four models recommended by FOCUS for estimation of pesticide leaching to groundwater [European Comission, 2014]. The results obtained by the successive versions of the program (most often groundwater concentrations, but also soil and air concentrations) were validated using the results of lysimeter and field studies, as well as groundwater monitoring results [Klein et al., 1997; Ferrari et al., 2005; Hardy et al., 2008; Klein, 2018].Simulations of tebuconazole leaching were carried out using the newest 5.5.3 version of PELMO [European Comission, 2014; Klein, 2018].

The necessary tebuconazole input data, i.e., its molecular mass (307.8 g), vapor pressure at $20{ }^{\circ} \mathrm{C}\left(1.310^{-6} \mathrm{~Pa}\right)$, and solubility in water at 20 ${ }^{\circ} \mathrm{C}$ and $\mathrm{pH} 7.2\left(7.2 \cdot 10^{-5} \mathrm{~Pa} \mathrm{~m} / \mathrm{mol}\right)$, were taken from the tebuconazole peer review [EFSA, 2014].

The cultivation of winter cereals was simulated, as they occupy the largest area of all crops in Poland, i.e., $39.7 \%$ of the total sown area in 2019 [GUS, 2020]. The emergence, maturity, senescence, and harvest dates were assumed to be on $5^{\text {th }}$ October, $10^{\text {th }}$ July, $16^{\text {th }}$ July, and $10^{\text {th }}$ August, respectively. Tebuconazole was assumed to be applied on $7^{\text {th }}$ May $(\mathrm{BBCH} 33)$ and $28^{\text {th }}$ May $(\mathrm{BBCH}$ 56 ) at doses of $0.25 \mathrm{~kg} / \mathrm{ha}$. After correction for crop interception ( $80 \%$ and $90 \%)$, the amounts applied to the soil were 0.05 and $0.025 \mathrm{~kg} / \mathrm{ha}$, respectively. Moreover, the cultivation of the winter oilseed rape was simulated, asthe rape and turnip rape occupied $8.0 \%$ of the total sown area in Poland in 2019 [GUS, 2020]. The emergence, maturity, senescence, and harvest dates were assumed to be on $2^{\text {nd }}$ September, $5^{\text {th }}$ May, $28^{\text {th }}$ June, and $28^{\text {th }}$ July, respectively. Tebuconazole was assumed to be applied on $10^{\text {th }}$ September (BBCH 15)

Table 1. Basic physicochemical properties of the examined soils

\begin{tabular}{|c|c|c|c|c|c|c|c|c|c|c|c|c|c|c|c|c|c|c|}
\hline \multirow{3}{*}{$\begin{array}{c}\text { Soil group } \\
\text { Soil code } \\
\text { Horizon }\end{array}$} & \multicolumn{6}{|c|}{ Arenosols } & \multicolumn{9}{|c|}{ Luvisols } & \multirow{2}{*}{\multicolumn{3}{|c|}{$\begin{array}{c}\text { Chernozem } \\
587\end{array}$}} \\
\hline & \multicolumn{3}{|c|}{611} & \multicolumn{3}{|c|}{805} & \multicolumn{3}{|c|}{824} & \multicolumn{3}{|c|}{590} & \multicolumn{3}{|c|}{564} & & & \\
\hline & $A p$ & BC & C & Ap & BC & C & $A p$ & Bt1 & Bt2 & $A p$ & Bt1 & Bt2 & $A p$ & Bt1 & Bt2 & Ap & A2 & $A C$ \\
\hline Sand (\%) & 88.5 & 96.5 & 98.0 & 85.0 & 95.0 & 89.5 & 51.5 & 62.5 & 66.5 & 78.0 & 57.0 & 48.0 & 18.0 & 16.0 & 14.0 & 16.5 & 15.5 & 14.5 \\
\hline Silt (\%) & 9.7 & 2.4 & 1.0 & 12.3 & 4.1 & 7.2 & 39.8 & 22.1 & 22.5 & 17.7 & 20.0 & 22.0 & 72.2 & 71.5 & 61.1 & 70.6 & 64.6 & 67.7 \\
\hline Clay (\%) & 1.8 & 1.1 & 1.0 & 2.7 & 0.9 & 3.3 & 8.7 & 15.4 & 11.0 & 4.3 & 23.0 & 30.0 & 9.8 & 12.5 & 24.9 & 12.9 & 19.9 & 17.8 \\
\hline $\mathrm{pH}$ & 5.0 & 4.6 & 4.5 & 4.2 & 5.1 & 5.6 & 5.5 & 4.5 & 4.6 & 4.5 & 4.8 & 4.6 & 7.0 & 6.8 & 6.9 & 7.1 & 7.3 & 7.5 \\
\hline OC (\%) & 1.13 & 0.09 & 0.03 & 0.68 & 0.04 & 0.04 & 1.08 & 0.19 & 0.11 & 0.88 & 0.16 & 0.09 & 1.36 & 0.48 & 0.31 & 1.92 & 1.31 & 0.67 \\
\hline $\mathrm{FC}(\mathrm{v} / \mathrm{v})^{\mathrm{a}}$ & 0.23 & 0.21 & 0.21 & 0.24 & 0.21 & 0.23 & 0.31 & 0.31 & 0.29 & 0.25 & 0.33 & 0.36 & 0.38 & 0.39 & 0.42 & 0.39 & 0.41 & 0.41 \\
\hline $\mathrm{K}_{\mathrm{F}}\left(\mu \mathrm{g}^{1-1 / n}(\mathrm{~mL})^{1 / n} \mathrm{~g}^{-1}\right)^{\mathrm{b}}$ & 16.7 & 1.2 & 1.2 & 14.9 & 1.2 & 1.1 & 14.2 & 8.3 & 6.4 & 13.4 & 4.3 & 6.5 & 13.1 & 4.9 & 3.2 & 16.9 & 7.9 & 4.2 \\
\hline $1 / \mathrm{n}^{\mathrm{b}}$ & 0.79 & 1.00 & 0.94 & 0.82 & 1.00 & 1.00 & 0.85 & 0.98 & 0.97 & 0.76 & 1.00 & 0.86 & 0.82 & 1.00 & 0.74 & 0.79 & 1.00 & 1.00 \\
\hline DT50 (d) ${ }^{\mathrm{c}}$ & 284 & 358 & 1234 & 135 & 658 & 566 & 203 & 813 & 1293 & 195 & 484 & 917 & 145 & 904 & 1536 & 247 & 675 & 1691 \\
\hline $\operatorname{DDF}^{\mathrm{d}}$ & 1 & 0.79 & 0.23 & 1 & 0.20 & 0.24 & 1 & 0.25 & 0.16 & 1 & 0.40 & 0.21 & 1 & 0.16 & 0.09 & 1 & 0.37 & 0.15 \\
\hline
\end{tabular}

${ }^{\mathrm{a}}$ calculated using the pedotransfer functions of PELMO [Klein, 2018]; ${ }^{\mathrm{b}}$ data from Siek et al. [2021]; ${ }^{\mathrm{c}}$ data at $20^{\circ} \mathrm{C}$ from Siek and Paszko [2019] recalculated to $10 \mathrm{kPa} ;{ }^{\mathrm{d}}$ depth-dependent degradation factor - ratio between the DT50 values for the topsoil and the respective subsoil horizon. 
and $29^{\text {th }}$ April (BBCH 53) at doses of 0.125 and $0.250 \mathrm{~kg} / \mathrm{ha}$. After correction for crop interception $(40 \%$ and $80 \%)$, the amounts applied to the soil were 0.075 and $0.050 \mathrm{~kg} / \mathrm{ha}$, respectively. The dates of particular crop development stages in the $\mathrm{BBCH}$ scale, the pesticide application dates, and the amounts intercepted by crops were estimated using the AppDate 3.06 software[Klein, 2018].

The DT50 values obtained in the previous study [Siek and Paszko, 2019] on tebuconazole degradation at $20{ }^{\circ} \mathrm{C}$ and soil moisture $\theta_{\mathrm{D}}(\mathrm{g} / \mathrm{g})$ were corrected to the reference water content at $10 \mathrm{kPa}$ assumed by FOCUS as the soil moisture at field capacity $\left(\theta_{\mathrm{FC}}-\right.$ estimated using the pedotransfer function of Pelmo). Thecorrection factor $f$ was calculated for each soil from the Walker equation $f=\left(\theta_{\mathrm{D}} / \theta_{\mathrm{FC}}\right)^{B}$ and correction was made by multiplying the DT50 values by $f$. The Walker moisture exponent $B$ was set to 0.7 [European Comission, 2014]. Next, the depth-dependent degradation factors for subsoils were calculated (DDF - ratio between the DT50 values in the topsoil and in the respective subsoil horizon). The corrected DT50 values and DDF values are presented in Table 1.The plant root uptake factor was set to the recommended value of 0.5 . For the temperature correction factor for degradation used in PELMO $\left(k_{T}=Q_{10}^{\frac{T-T_{r}}{10}}\right)$, where $T$ denotes the actual soil temperature, and $T_{r}$ is the reference temperature $\left(20^{\circ} \mathrm{C}\right)$ at which degradation experiments should be carried out), the value of $Q_{10}=$ 2.58 recommended by the European Comission [2014] was used. The thickness of the topsoil and two subsoils were set to $25 \mathrm{~cm}, 35 \mathrm{~cm}$, and $40 \mathrm{~cm}$, respectively. Additionally, the forth subsoil horizon with a thickness of $20 \mathrm{~cm}$ was added. Its parameters were identical to the lower subsoil horizon, with the exception of the DDF value, which was set to 0 . The dispersion length of the layers of the $120 \mathrm{~cm}$ profiles was set to $5 \mathrm{~cm}$ [European Comission, 2014]. The potential evapotranspiration (the sum of evaporation and transpiration) was calculated using the Hamon equation [Klein, 2018]. The soil hydraulic parameters (soil moisture at field capacity $-10 \mathrm{kPa}$, and at wilting point $-1600 \mathrm{kPa}$ ) were calculated using the pedotransfer functions of PELMO [Klein, 2018].

The climate data from 1990 to 2009 obtained from the Hydro-Meteorological Station LublinRadawiec $\left(51^{\circ} 13^{\prime} \mathrm{N}, 22^{\circ} 24^{\prime} \mathrm{E}\right)$ of the Institute of Meteorology and Water Management were used in the climate file. The 26-year simulation period was obtained by initial repetition of the first 6 years.
In order to avoid an unrealistic worst case scenario, which can be obtained when only the worst case parameters are selected for simulations (e.g. the largest of the DT50 values obtained for the Ap horizon together with the lowest DDF values for subsoils),only the adsorption and degradation parameters of the individual horizons presented in Table 1 were used in simulations. This method in general averaged the obtained extremal parameters.

\section{RESULTS}

\section{Fate of tebuconazole in soils - analysis of the mass balance}

The tebuconazole mass balance analysis indicated that after the simulated application thereof to the soil during the cultivation of winter cereals, only $0.026 \mathrm{~g} / \mathrm{ha} \pm 0.005$ (standard deviation) of the fungicide was volatilized to air each year, and $0.051 \mathrm{~g} / \mathrm{ha} \pm 0.015$ was volatilized in the case of the winter rape cultivation (in both cases $\sim 0.04 \%$ of the applied doses). The variance of the obtained results originated primarily from the differences in climatic factors (mainly temperature) during the 20-year simulation period. Tebuconazole is a low volatile compound; its Henry's law constant at $20{ }^{\circ} \mathrm{C}$ is only $1 \cdot 10^{-5} \mathrm{~Pa} \mathrm{~m}^{3} / \mathrm{mol}$ [EFSA, 2014].

As it was already mentioned, the plant root uptake factor was set to the default value 0.5. This indicates that the fungicide content taken up by the plant roots is $50 \%$ of the soil water concentration in the respective soil layer [Klein, 2018]. However, since the $K_{F}$ values of the Freundlich adsorption coefficient were high in the majority of soils (Table 1), the tebuconazole concentrations in the soil water were very low. Therefore, the estimated mean yearly tebuconacole uptake by the roots of the winter cereals was only $1.29 \pm 0.32 \mathrm{~g} / \mathrm{ha}(1.8 \%$ of the dose of $75 \mathrm{~g})$ and only $2.33 \pm 0.57 \mathrm{~g} / \mathrm{ha}(1.9 \%$ of the dose of $125 \mathrm{~g}$ ) in the case of the winter rape cultivation. Thus, the simulations indicated that, due to its high adsorption in soils, tebuconazole is weakly available to the plant root systems. This finding is consistent with the data published by FAO [2011], which indicated that after application of tebuconazole onto bare soil at a rate of $0.5 \mathrm{~kg} / \mathrm{ha}$, its accumulation in the straw and grain of winter wheat was $<0.05 \mathrm{mg} / \mathrm{kg}$. 
The tebuconazole mass balance analysis showed that during the simulations of the cultivation of the winter cereals, $73.49 \pm 4.34 \mathrm{~g} / \mathrm{ha}$ ( $98.4 \%$ of the applied doses) of the fungicide was degraded each year in the soil, and 122.53 $\pm 6.21 \mathrm{~g} / \mathrm{ha}(97.1 \%$ of the applied doses)was degraded in the case of the winter rape cultivation. Thus, in most of the analyzed years, practically the entire applied doses of tebuconazole were degraded in the examined soil profiles. In the years in which the weather conditions were less favorable to its degradation (the microbial degradation rate increases as temperature and soil moisture increase), up to $8.1 \mathrm{~g} / \mathrm{ha}$ of the applied compound in the case of the winter cereal cultivation $(10.7 \%$ of dose) and up to $14.4 \mathrm{~g} /$ ha during the winter rape cultivation ( $11.6 \%$ of dose) were not degraded to the end of the year. However, in the successive years,most of these amounts were degraded or taken up by the plant roots.

\section{Concentration of tebuconazole in the soil solid phase}

The concentrations of tebuconazole adsorbed in the topsoil layer of $0-5 \mathrm{~cm}$ are presented in Figure 2a-b. The most probable range of concentrations is that between the Q1 and Q3 quartile, i.e., the range of $0.069-0.320 \mathrm{mg} / \mathrm{kg}$ of soil for both crops. It is visible that the concentrationsin the $611^{\text {th }}$ and $587^{\text {th }}$ profiles are much higher than in the other profiles. This is caused by the lowest degradation rates in the Ap horizon (DT50 of 284 and 247 days; Table 1), the highest $K_{F}$ values (16.7 and $16.9 \mu \mathrm{g}^{1-1 / \mathrm{n}}(\mathrm{mL})^{1 / \mathrm{n}} \mathrm{g}^{-1}$ ), and the low $1 / n$ value (0.79). The concentrations of the fungicide in the $5-10 \mathrm{~cm}$ layer were much lower. Taking into account both crops as well as Q1 and Q3 quartiles, the most probable range in this layer was $0.022-0.118 \mathrm{mg} / \mathrm{kg}$. As in the $0-5 \mathrm{~cm}$ layer, the highest retention of tebuconazole was recorded in the $611^{\text {th }}$ and $587^{\text {th }}$ profiles. Taking into account the Q1 and Q3 quartile and simulations in both crops, the concentrations in the $10-15 \mathrm{~cm}$ layer (Fig. 2e-f) were in the range of $0.004-0.035 \mathrm{mg} /$ $\mathrm{kg}$. Besides the 611 th and 587th profiles, the third highest concentration of tebuconazole in soil was estimated in the $824^{\text {th }}$ profile, where the values of DT50 (203 days) and $K_{F}\left(14.2 \mu \mathrm{g}^{1-1 / \mathrm{n}}(\mathrm{mL})^{1 / \mathrm{n}} \mathrm{g}^{-1}\right)$ were high, and the $1 / n$ value $(0.85)$ wasstill low. It is worth noting that the penetration of tebuconazole through $10 \mathrm{~cm}$ of the Ap horizon caused a $\sim 10$-fold decrease in its concentration in the soil.
Figure $2 \mathrm{~g}$-h shows that the fungicide was able to penetrate up to $20 \mathrm{~cm}$ depth of the plow layer. In two profiles in the case of the winter oilseed rape cultivation and in three profiles in the case of the winter cereal cultivation, the concentrations of tebuconazole were $<0.002 \mathrm{mg} / \mathrm{kg}$ in the $15-20 \mathrm{~cm}$ layer, i.e., below the detection limit of the monitoring studies (see, e.g., Tauchnitz et al. [2020]). In the $611^{\text {th }}, 824^{\text {th }}$, and $587^{\text {th }}$ profiles, in which the retention of tebuconazole was higher, the concentrations (again Q1 and Q3 quartiles were taken into account) were in the range of $0.002-0.007 \mathrm{mg} / \mathrm{kg}$ for both crops.

Changes inthe mean yearly temperature and precipitation as well as an example of the pattern of changes in thetebuconazole concentrations in the Ap horizon of the 611 profile during the last 20 years of the 26-year simulation period of winter oilseed rape cultivation are presented in Figure $3 \mathrm{a}-\mathrm{c}$. High yearly fluctuations are visible in the $0-5 \mathrm{~cm}$ layer. They are connected with the application of tebuconazole twice a year and its disappearance resultingfrom microbial degradation and,to a much lesser extent, from its uptake by plant roots and volatilization. There are also visible small differences in concentrations resulting from the differences in climatic factors. The fluctuations in the lower layers are smaller; there is also a still visible difference in the concentrations in the individual years associated mainly with the differences in temperature and precipitation and the slight accumulation of tebuconazole in the first 10 years of simulations.

Although the data presented in Figs. 2-3 are the results of the simulations, a comparison of these data with thosefound in the literature confirms that they are consistent. Amonitoring study carried out in European agricultural soils (including Poland) by Silva et al. [2019] indicated that the median of tebuconazole concentrations in the soil samples collected from the $0-20 \mathrm{~cm}$ layer was $0.02 \mathrm{mg} / \mathrm{kg}$ and the maximum concentration was $0.19 \mathrm{mg} / \mathrm{kg}$. Similar ranges of concentrations were detectedby the authors also for other azole fungicides. Azole fungicides were also commonly detected in the Czech Republic by Hvezdova et al. [2018]. Among them, tebuconazole was in the second place with concentrations in the soil samples from the depth of $0-25 \mathrm{~cm}$ in the range of $0.01-0.03 \mathrm{mg} / \mathrm{kg}$. Moreover, tebuconazole was examined in the topsoil samples in SaxonyAnhalt in central Germany by Tauchnitz et al. [2020]. In the analyzed catchment, tebuconazole 
Winter oilseed rape
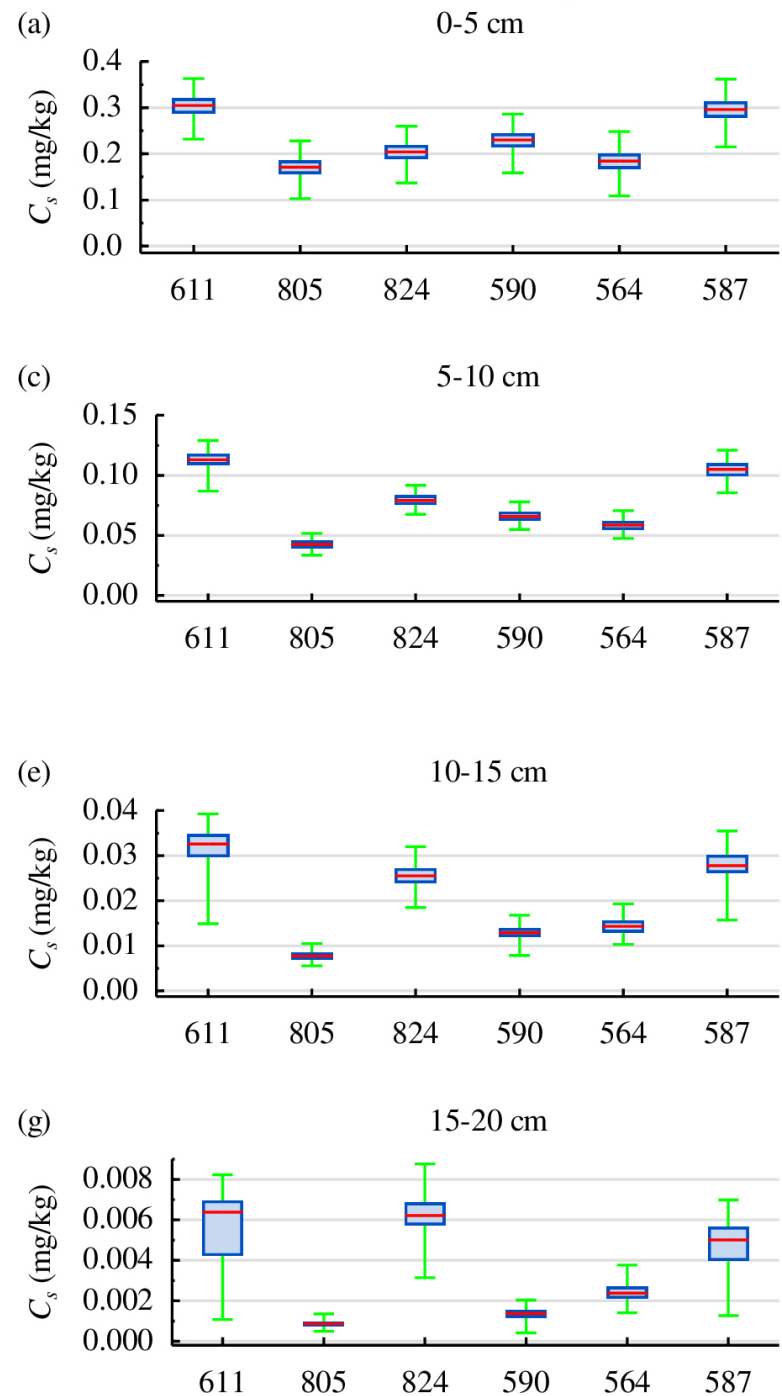

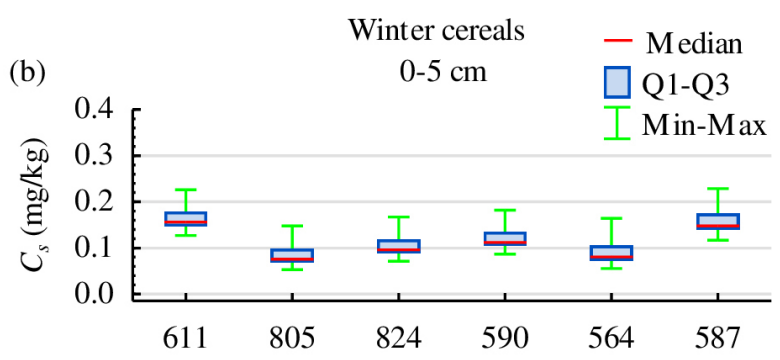

(d)

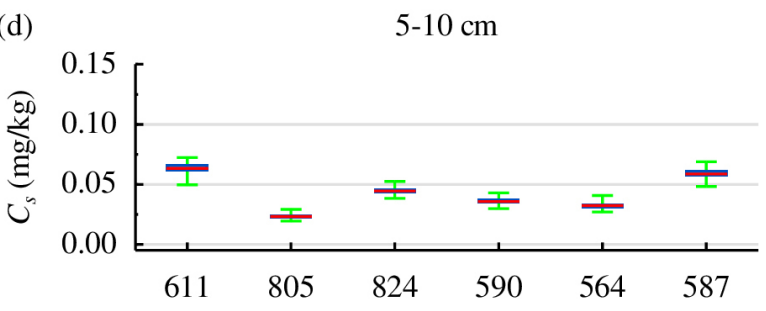

(f)

$10-15 \mathrm{~cm}$

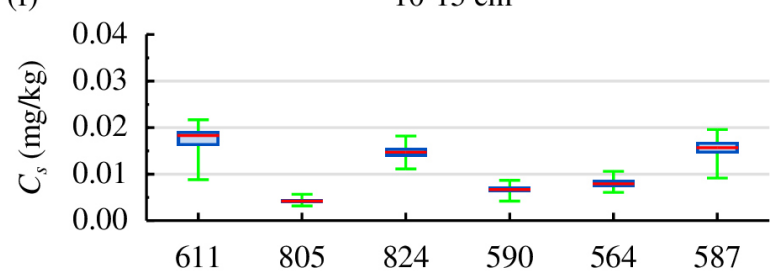

(h)

$15-20 \mathrm{~cm}$

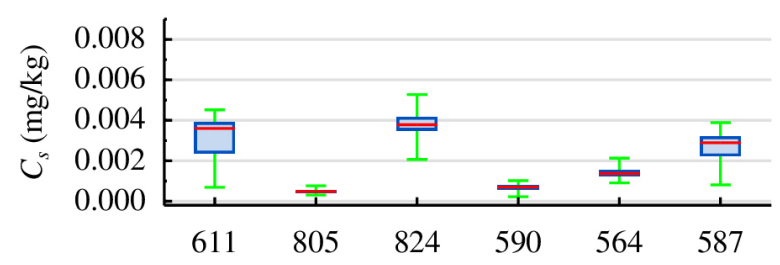

Figure 2. Predicted concentrations of tebuconazole $\left(C_{s}\right)$ in the selected soil depths during the simulated winter oilseed rape and winter cereals cultivation
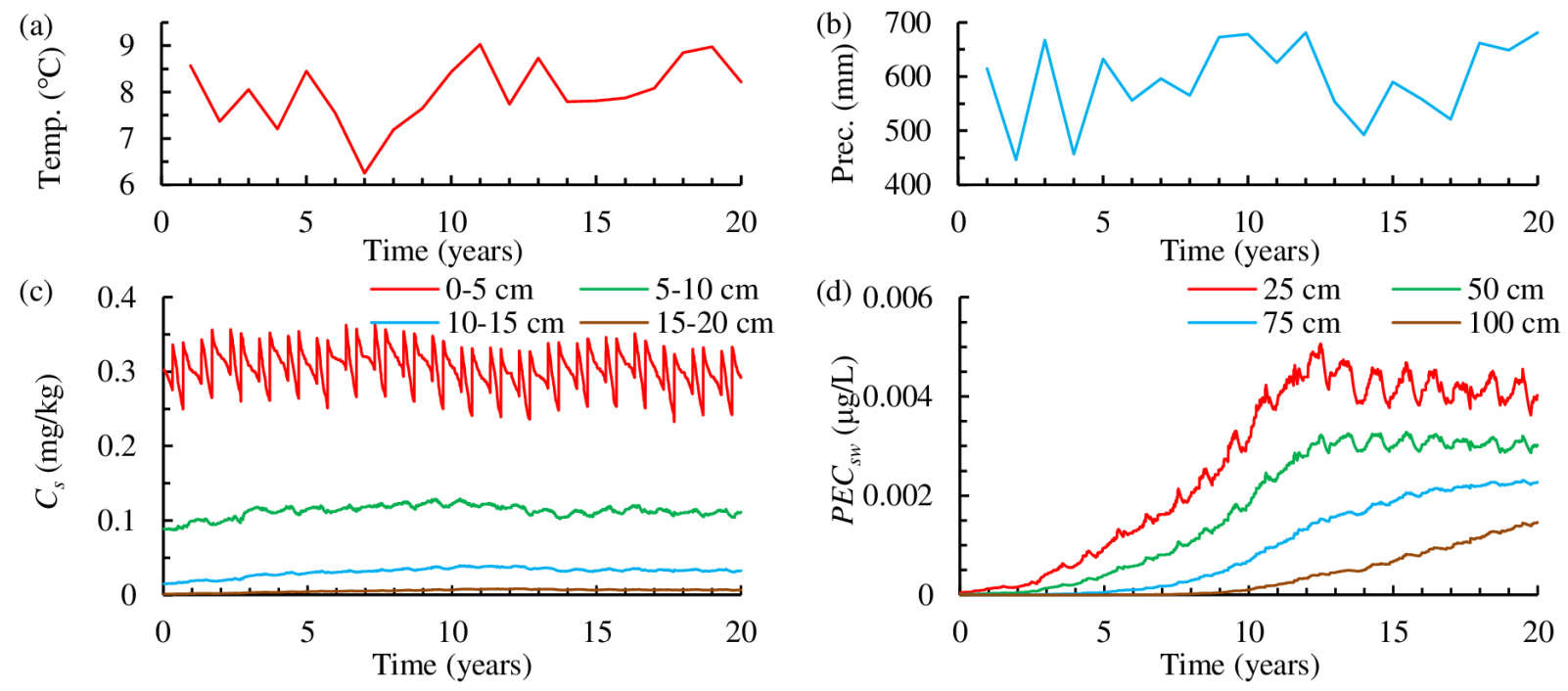

Figure 3. Mean yearly temperature (a) and precipitation (b) as well as predicted soil concentrations $\left(C_{s}\right)$ of tebuconazole (c) and its concentration in soil water $\left(P E C_{s w}\right)$ in the selected soil depths (d) during the simulated winter oilseed rape cultivation 
was the most frequently used pesticide. The majority of soils analyzed by the authors were classified as Chernozems and Luvisols developed from loess (i.e., similar to the $587^{\text {th }}$ and $564^{\text {th }}$ profiles). In addition, the climate was very similar to the climate in this study, with themean precipitation of $550 \mathrm{~mm}$ (in this study $595 \mathrm{~mm}$ ), maximum precipitation in summer months, and mean annual air temperature of $9.0^{\circ} \mathrm{C}$ (in this study $8.0^{\circ} \mathrm{C}$ ). The soil concentrations of tebuconazole in the topsoil $(0-30 \mathrm{~cm})$ samples were in the range of $0.003-0.090 \mathrm{mg} / \mathrm{kg}$. Moreover, the authors detected tebuconazole at concentrations $0.003-0.004 \mathrm{mg} / \mathrm{kg}$ in two of five analyzed subsoil samples $(30-90 \mathrm{~cm})$.

The results of the study conducted by Tauchnitz et al. [2020]suggest that the movement of tebuconazole to subsoils can be slightly higher than that presented in Figures 2-3. One of the causes may be associated with macropore flow, i.e., preferential transport of pesticide down the soil profile through well-connected discontinuities, such as wormholes and fractures. However, sincea significant contribution of this kind of pesticide transport was observed mainly in loamy soils, and in sandy soils percolation of water through the unsaturated zone resembled most often piston flow [Rosenbom et al., 2015], the option of the macropore flow was not used in this study.Taking into account the results of a study conducted by Albers et al. [2019] tebuconazole transport can be facilitated by sorption to mobile colloids (dissolved organic matter, water soluble manure or compost colloids) at the soil surface and sorption of these colloids in deeper soil layers. However, as in the case of macropore transport, this kind of transport is very difficult for precise modeling. Thus, it seems unquestionable that tebuconazole is accumulated predominantly in the topsoil layer $0-15 \mathrm{~cm}$ and only very small amounts of the fungicide are transported below this layer. A leaching experiment involving columns packed with sandy loam with low OC contents $(0.4-0.5 \%)$ conducted by Singh [2005] indicated that triazole fungicides were retained mainly on the top of the column $(0-5 \mathrm{~cm})$, and after percolating three pore volumes of water they moved down only to $10-15 \mathrm{~cm}$ (penconazole, hexaconazole, and propiconazole) or to $15-20 \mathrm{~cm}$ depth (triadimefon). A lysimetric study carried out by Kim et al. [2002] indicated that propiconazone was retained in soils mainly in the $0-10 \mathrm{~cm}$ layer, and the amounts retained below $20 \mathrm{~cm}$ depth were in the range of $0.9-2.1 \%$.

\section{Concentration of Tebuconazole in Soil Water}

The concentrations of tebuconazole in the soil water obtained during the simulated cultivation of winter oilseed rape and winter cereals from the 20-year simulation period $\left(\mathrm{PEC}_{\mathrm{sw}}\right)$ at 25,50 , and $75 \mathrm{~cm}$ depth are presented in Figure 4. The concentrations are generally very low, as tebuconazole was strongly adsorbed in the soils (see $K_{F}$ values in Table 1) and its concentrations in the solid phase in each examined soil horizonwere higher than its concentrations in the liquid phase $\left(K_{F}>1\right)$. The highest concentrations, observed for the $824^{\text {th }}$ and $611^{\text {th }}$ profiles, were associated with itsslow degradationin top- and subsoils (Table 1), and high values of $1 / n$ in the subsoils. The highest $\mathrm{PEC}_{\mathrm{sw}}$ values for the $611^{\text {th }}$ profile at $75 \mathrm{~cm}$ depth (median range for both cropsof 0.0004-0.0007 $\mu \mathrm{g} / \mathrm{L}$ and Q3 range of $0.0010-0.0019 \mu \mathrm{g} / \mathrm{L}$ ) were associated primarily with very low $K_{F}\left(1.2 \mu \mathrm{g}^{1-1 / \mathrm{n}}\right.$ $\left.(\mathrm{mL})^{1 / n} \mathrm{~g}^{-1}\right)$ for this profile and high $1 / n(1.00)$ values in the $\mathrm{BC}$ horizon. It is worth mentioning that in the $611^{\text {th }}$ profile in the last years of simulations, trace concentrations of tebuconazole were also obtained at a depth of $100 \mathrm{~cm}$. Figure $3 \mathrm{~d}$ clearly shows that tebuconazole is present in pore water at depths $25-100 \mathrm{~cm}$ in higher concentrations after 10 or more years of simulations ( 16 or more years after includingthe initial 6 years). Therefore, the simulations suggest that the existence of detectable concentrations of tebuconazole in ground water in monitoring studies are associated withits continuous application in the same area for many years, and accumulation of its small amounts in the solid phase of soils in subsoil horizons.

The Danish Pesticide Leaching Assessment Program indicated that the highest tebuconazole concentrations in ground water at $1 \mathrm{~m}$ depth (range of $0.05-2 \mu \mathrm{g} / \mathrm{L}$ ) were detected in the soils with texture of sandy loam, in which the preferential transport occurred [Rosenbom et al., 2015]. In the soils with texture of sand and loamy sand, in which the piston flow was dominant, detectable concentrations of the fungicide were detected only in a few samples, with maximum concentrationsof $0.01 \mu \mathrm{g} / \mathrm{L}$. The concentrations of azole fungicides in drainage water determined in the lysimetric studies by Aamlid et al. [2021] simulating pesticide leaching in golf courses (where they are frequently used)were also low - in the range 

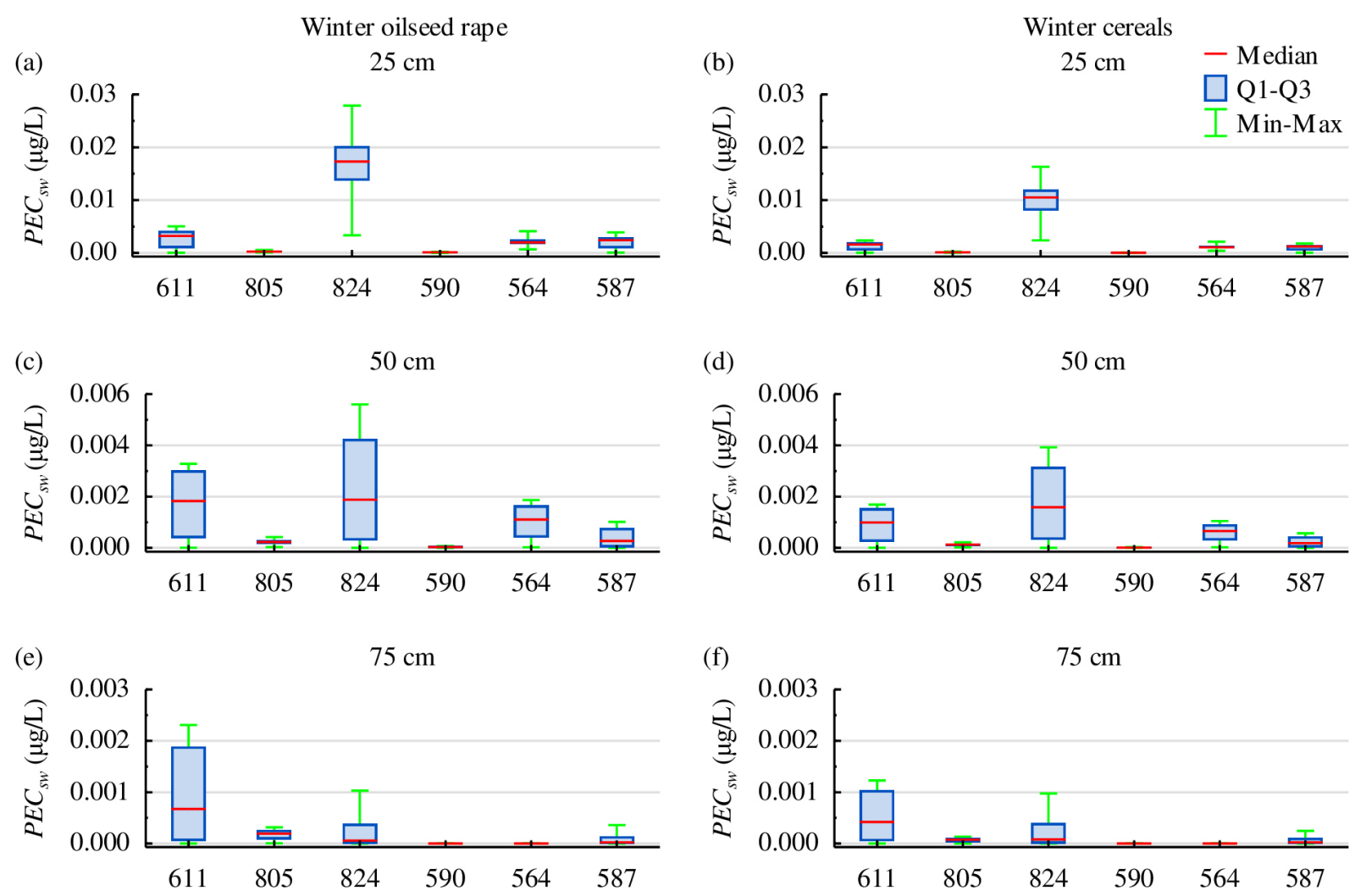

Figure 4. Predicted concentrations of tebuconazole in soil water $\left(\mathrm{PEC}_{\mathrm{sw}}\right)$ in the selected soil depths during the simulated winter oilseed rape and winter cereal cultivation.

of $0.003-0.015 \mu \mathrm{g} / \mathrm{L}$. Thus, the results of our studies, which signalize that the existence of higher concentrations of tebuconazole in groundwater at $1 \mathrm{~m}$ depth is unlikely in the examined soils, is consistent with the results obtained by the abovementioned authors. As was mentioned earlier, higher concentrations (also $<0.1 \mu \mathrm{g} / \mathrm{L}$ ) may occur in the soils with high content of clay in which preferential transport is likely, and due to the fact that dissolved organic matter and dissolved in water organic colloids of manure or compost can, to some extent, enhance of tebuconazole transport to subsoils [Chabauty et al., 2016]. Therefore, the actual concentrations of tebuconazole in soil water can be slightly higher than these presented in Figures 3-4. The underestimation of fungicide leaching by the FOCUS pesticide leaching programs, relatively high in the first tier based on the $K_{F o c}$ concept, was signalized by Knäbel et al. [2014]. Therefore, the adsorption and degradation parameters, carefully determined for each examined horizon,were used to avoid this, as they are crucial factors for correct estimation of pesticide retention and leaching.

The analysis of the obtained data suggests that high concentrations of tebuconazole in the $0-5 \mathrm{~cm}$ soil level (Figs. 2-3) are the principal source of the fungicide in the surface water in agricultural regions. The runoff water mixes with the pore water from this soil level, wherethe highest concentrations of tebuconazole are recorded, desorbs part of tebuconazole adsorbed in the soil solid phase, and flows into drainage ditches, canals, streams, rivers, and lakes, where seasonal concentrations of tebuconazole can exceed the allowable level of $0.1 \mu \mathrm{g} / \mathrm{L}$. As already mentioned, >> $0.1 \mu \mathrm{g} / \mathrm{L}$ concentrations of tebuconazole in surface water were detected by Berenzen et al. [2005], Potter et al. [2014], and Rabiet et al. [2010].

Figure $4 \mathrm{a}-\mathrm{f}$ showed the highest $\mathrm{PEC}_{\mathrm{sw}}$ values for the coarse soils, i.e., the 611 and 805 Arenosol profiles formed from sand and the 824 Luvisol profile formed from sandy loam. The tebuconazole leaching in the soils developed from loess (564 and 587 profile) was negligible. Sandy soils very often exhibitthe highest leaching potential, which was indicated in monitoring studies [Leterme et al., 2006; Hardy et al., 2008]. Profiles of sandy soils often have low organic matter contents (especially in subsoils), which affects their sorption capacity and microbial activity. Moreover, such soils have low water capacity (compare the FC values in Table 1) andhigh water permeability, which increases pesticide leaching. 


\section{CONCLUSIONS}

The simulations with FOCUS PELMO indicated that after the application of tebuconazole to winter cereals and winter oilseed rape,mostof the fungicide reaching the soil surface was retained in the topsoil layer of $0-15 \mathrm{~cm}$. The highest fungicide concentrations in soils (range of 0.069$0.320 \mathrm{mg} / \mathrm{kg}$ ) were predicted for the layer of $0-5 \mathrm{~cm}$, whereas much lower levels were found for the $5-10 \mathrm{~cm}$ and $10-15 \mathrm{~cm}$ layers (ranges of $0.022-0.118$ and $0.004-0.035 \mathrm{mg} / \mathrm{kg}$, respectively). The simulations indicated that 97-98\% of tebuconazole retained in the soils was microbiologically degraded. However, in years in which the weather conditions were unfavorable for degradation, up to $\sim 11 \%$ of the fungicide retained in soils remained undegraded for the following year. The simulations demonstrated accumulation of tebuconazole in topsoils and its very slow but constant penetration to subsoils. The estimated uptake of tebuconazole by plant roots was low, i.e., $<2 \%$ of the dose that reached the soils. The concentrations of tebuconazole in pore water were low as well: $<0.02 \mu \mathrm{g} / \mathrm{L}$ at the depth of $25 \mathrm{~cm}$ and $<0.002 \mu \mathrm{g} / \mathrm{L}$ at the depth of $75 \mathrm{~cm}$. Trace concentrations of tebuconazole at the depth of $1 \mathrm{~m}$ were estimated only in one profile. Thus, the simulations clearly indicated that tebuconazole leaching to groundwater was unlikely in the examined profiles. Taking this into account, runoff is the principal source of tebuconazole in surface water.

\section{Acknowledgments}

The authors wish to express their gratitude to the Institute of Agrophysics, Polish Academy of Sciences in Lublin for providing data from the database and soil collection of Polish arable soils and the Institute of Meteorology and Water Management for providing the climate data.

\section{REFERENCES}

1. Aamlid T.S., Almvik M., Pettersen T., Bolli R. 2021. Leaching and surface runoff after fall application of fungicides on putting greens. Agronomy Journal, 1-21. DOI: 10.1002/Agj2.20549.

2. Albers C.N., Ernstsen V., Johnsen A.R. 2019. Soil domain and liquid manure affect pesticide sorption in macroporous clay till. Journal of Environmental Quality, 48(1), 147-155. DOI: 10.2134/ jeq2018.06.0222.

3. Berenzen N., Lentzen-Godding A., Probst M., Schulz H., Schulz R., Liess M. 2005. A comparison of predicted and measured levels of runoff-related pesticide concentrations in small lowland streams on a landscape level. Chemosphere, 58(5), 683-691. DOI: 10.1016/j.chemosphere.2004.05.009.

4. Bernasconi C., Demetrio P.M., Alonso L.L., Mac Loughlin T.M., Cerdá E., Sarandón S.J., Marino D.J. 2021. Evidence for soil pesticide contamination of an agroecological farm from a neighboring chemical-based production system. Agriculture Ecosystems \& Environment, 313, 107341. DOI: 10.1016/J.Agee.2021.107341.

5. Bieganowski A., Witkowska-Walczak B., Gliński J., Sokołowska Z., Sławiński C., Brzezińska M., Włodarczyk T. 2013. Database of Polish arable mineral soils: a review. International Agrophysics, 27, 335-350. DOI: 10.2478/intag-2013-0003.

6. Bollmann U.E., Fernández-Calviño D., Brandt K.K., Storgaard M.S., Sanderson H., Bester K. 2017. Biocide runoff from building facades: Degradation kinetics in soil. Environmental Science \& Technology, 51(7), 3694-3702. DOI: 10.1021/acs. est.6b05512.

7. Chabauty F., Pot V., Bourdat-Deschamps M., Bernet N., Labat C., Benoit P. 2016. Transport of organic contaminants in subsoil horizons and effects of dissolved organic matter related to organic waste recycling practices. Environmental Science and Pollution Research, 23(7), 6907-6918. DOI: 10.1007/ s11356-015-5938-9.

8. Comission of the European Communities, 1991. Council directive 91/414/EEC concerning the placing of plant protection products on the market. Official Journal of the European Communities, L, 230.

9. De Gerónimo E., Aparicio V.C., Bárbaro S., Portocarrero R., Jaime S., Costa J.L. 2014. Presence of pesticides in surface water from four sub-basins in Argentina. Chemosphere, 107, 423-431. DOI: 10.1016/j.chemosphere.2014.01.039.

10. EFSA. 2014. Conclusion on the peer review of the pesticide risk assessment of the active substance tebuconazole. EFSA J, 12(1), 3485, 1-98. DOI: $10.2903 /$ j.efsa. 2014.3485 .

11. European Comission. 2014. Assessing potential for movement of active substances and their metabolites to ground water in the EU. Report of the FOCUS Ground Water Work Group.

12. European Comission. 2020. Commission Decision 2020/1161 of 4 August 2020. Official Journal of the European Union L 257/32.

13. European Comission. 2021a. EU Pesticides Database. [cited 2021 August 12]. Available from: https://ec.europa.eu/food/plants/pesticides/ eu-pesticides-database_en. 
14. European Comission. 2021b. Eurostat. [cited 2021 August 12]. Available from: https:// ec.europa.eu/eurostat/databrowser/view/AEI_ FM_SALPEST09_custom_1213735/default/ table?lang=en.

15. FAO. 2011. Caldas E. D. Tebuconazole (189). Residue and analytical aspects. [cited 2021 August 12]. Available from: http://www.fao.org/fileadmin/user_ upload/IPM_Pesticide/JMPR/Evaluations/2011/Tebuconazole.pdf.

16. Ferrari F., Klein M., Capri E., Trevisan M. 2005. Prediction of pesticide volatilization with PELMO 3.31. Chemosphere, 60, 705-713. DOI: 10.1016/j. chemosphere.2005.01.043.

17. GUS. 2020. Statistical yearbook of agriculture. Branch yearbooks. Central Statistical Office, Warsaw.

18. Hardy I., Gottesbüren B., Huber A., Jene B., Reinken G., Resseler H. 2008. Comparison of Lysimeter results and leaching model calculations for regulatory risk assessment. Journal of Consumer Protection and Food Safety, 3, 364-375. DOI: 10.1007/ s00003-008-0376-y.

19. Hvezdova M., Kosubová P., Košiková M., Scherr K.E., Simek Z., Brodsky L., Šudoma M., Škulcová L., Sanka M., Svobodová M., Krkošková L., Vašičková J., Neuwirthová N., Bielska L., Hofman J. 2018. Currently and recently used pesticides in Central European arable soils. Science of the Total Environment, 613-614, 361-370. DOI: 10.1016/j. scitotenv.2017.09.049.

20. ISO 10390. 2020. Soil, treated biowaste and sludge - Determination of $\mathrm{pH}$.

21. ISO 11277. 2020. Soil quality - Determination of particle size distribution in mineral soil material Method by sieving and sedimentation.

22. IUSS Working Group WRB. 2015. World reference base for soil resources 2014, update 2015. International soil classification system for naming soils and creating legends for soil maps. World soil Resources Reports No. 106. FAO, Rome.

23. Kahle M., Buerge I.J., Hauser A., Müller M.D., Poiger T. 2008. Azole fungicides: Occurrence and fate in wastewater and surface waters. Environmental Science \& Technology, 42(19), 7193-7200. DOI: 10.1021/es8009309.

24. Kim I.S., Beaudette L.A., Shim J.H., Trevors J.T., Suh Y.T. 2002. Environmental fate of the triazole fungicide propiconazole in a rice-paddy-soil lysimeter. Plant and Soil, 239(2), 321-331. DOI: 10.1023/A:1015000328350.

25. Klein M. 2018. PELMO (Pesticide Leaching Model)). Version 5.00. User Manual. Fraunhofer Institut for Molecular Biology and Applied Ecology, D-57392 Schmallenberg, Germany, 30.
26. Klein M., Müller M., Dust M., Görlitz G., Gottesbüren B., Hassink J., Kloskowski R., Kubiak R., Resseler H., Schäfer H., Stein B., Vereecken H. 1997. Validation of the pesticide leaching model PELMO using lysimeter studies performed for registration. Chemosphere, 35(11), 2563-2587. DOI: 10.1016/S0045-6535(97)00325-1.

27. Knäbel A., Meyer K., Rapp J., Schulz R. 2014. Fungicide field concentrations exceed FOCUS surface water predictions: urgent need of model improvement. Environmental Science \& Technology, 48(1), 455-463. DOI: 10.1021/es4048329.

28. Kördel W., Klein M. 2006. Prediction of leaching and groundwater contamination of pesticides. Pure and Applied Chemistry, 78(5), 1081-1090. DOI: 10.1351/pac200678051081.

29. Leterme B., Vanclooster M., Rounsevell M.D., Bogaert P. 2006. Discriminating between point and nonpoint sources of atrazine contamination of a sandy aquifer. Science of the Total Environment, 362(13), 124-142. DOI: 10.1016/j.scitotenv.2005.06.010.

30. Lewis K.A., Tzilivakis J., Warner D.J., Green A. 2016. An international database for pesticide risk assessments and management. Human and Ecological Risk Assessment, 22, 1050-1064. DOI: 10.1080/10807039.2015.1133242.

31. Liu N., Dong F.S., Xu J., Liu X.G., Zheng Y.Q. 2016. Chiral bioaccumulation behavior of tebuconazole in the zebrafish (Danio rerio). Ecotoxicology and Environmental Safety, 126, 78-84. DOI: 10.1016/j.ecoenv.2015.12.007.

32. Matyjaszczyk E. 2011. Active substances used in plant protection in Poland after the European Union accession. Journal of Plant Protection Research, 51(3), 217-224. DOI: 10.2478/ v10045-011-0037-5.

33. Matysiak K., Kaczmarek S. 2013. Effect of chlorocholine chloride and triazoles - tebuconazole and flusilazole on winter oilseed rape (Brassica Napus var. Oleifera L.) in response to the application term and sowing density. Journal of Plant Protection Research, 53(1), 79-88. DOI: 10.2478/ jppr-2013-0012.

34. Ministry of Agriculture and Rural Development, 2021. The register of authorized plant protection products. [cited 2021 August 12]. Available from: https:/www.gov.pl/web/rolnictwo/ rejestr-rodkow-ochrony-roslin.

35. Pérez D.J., Okada E., De Gerónimo E., Menone M.L., Aparicio V.C., Costa J.L. 2017. Spatial and temporal trends and flow dynamics of glyphosate and other pesticides within an agricultural watershed in Argentina. Environmental Toxicology and Chemistry, 36(12), 3206-3216. DOI: 10.1002/etc.3897.

36. Potter T.L., Bosch D.D., Strickland T.C. 2014. Comparative assessment of herbicide and fungicide 
runoff risk: A case study for peanut production in the Southern Atlantic Coastal Plain (USA). Science of the Total Environment, 490, 1-10. DOI: 10.1016/j. scitotenv.2014.04.034.

37. Rabiet M., Margoum C., Gouy V., Carluer N., Coquery, M., 2010. Assessing pesticide concentrations and fluxes in the stream of a small vineyard catchment - Effect of sampling frequency. Environmental Pollution, 158(3), 737-748. DOI: 10.1016/j. envpol.2009.10.014.

38. Rosenbom A.E., Olsen P., Plauborg F., Grant R., Juhler R.K., Brüsch W., Kjaer J. 2015. Pesticide leaching through sandy and loamy fields - long-term lessons learnt from the Danish Pesticide Leaching Assessment Programme. Environmental Pollution, 201, 75-90. DOI: 10.1016/j.envpol.2015.03.002.

39. Siek M., Paszko T. 2019. Factors affecting coupled degradation and time-dependent sorption processes of tebuconazole in mineral soil profiles. Science of the Total Environment, 690, 1035-1047. DOI: 10.1016/j.scitotenv.2019.06.409.

40. Siek M., Paszko T., Jerzykiewicz M., Matysiak J., Wojcieszek U. 2021. Mechanisms of tebuconazole adsorption in profiles of mineral soils. Molecules 26, 4728. DOI: 10.3390/molecules26164728.

41. Silva V., Mol H.G.J., Zomer P., Tienstra M., Ritsema C.J., Geissen V. 2019. Pesticide residues in European agricultural soils - A hidden reality unfolded. Science of the Total Environment, 653, 1532-1545. DOI: 10.1016/j.scitotenv.2018.10.441.

42. Singh N. 2005. Mobility of four triazole fungicides in two Indian soils. Pest Management Science, 61(2), 191-196. DOI: 10.1002/ps.973.

43. Tauchnitz N., Kurzius F., Rupp H., Schmidt G., Hauser B., Schrödter M., Meissner R. 2020. Assessment of pesticide inputs into surface waters by agricultural and urban sources - A case study in the Querne/Weida catchment, central Germany. Environmental Pollution, 267, 115186. DOI: 10.1016/j. envpol.2020.115186.

44. Van Metre P.C., Alvarez D.A., Mahler B.J., Nowell L., Sandstrom M., Moran P. 2017. Complex mixtures of pesticides in midwest US streams indicated by POCIS time-integrating samplers. Environmental Pollution, 220, 431-440. DOI: 10.1016/j. envpol.2016.09.085. 